\title{
Application of some vegetables extracts on storage period of corn and linseed oils
}

\author{
Ahmed A. Aly, Nawal A. Tahoon, Rehab N. Elhelaly
}

Home economics Department, Faculty of Specific Education, Benha University, Egypt

\begin{abstract}
7 his study aimed to determine the phenolic and flavonoids content of carrot, cabbage and green pepper extracts and their effects on some 1 chemical properties of corn and linseed oils during storage period.
\end{abstract} Phenolic and flavonoids content were determined by high performance liquid chromatographic method using ultraviolet $(U V)$ detector set at $280 \mathrm{~nm}$ and $330 \mathrm{~nm}$, respectively. Corn and linseed oils storied (Six months) at room temperature $\left(25 \pm 5^{\circ} \mathrm{C}\right)$ after additional $500 \mathrm{ppm}, 1000 \mathrm{ppm}$ and $1500 \mathrm{ppm}$ from carrot, cabbage and green pepper extracts and compared with additional 200 ppm synthetic antioxidants (BHT \& BHA). The oils samples analyzed every month for acid, peroxide and iodine values during storage period. The results showed that in the end of storage period acid and peroxide values of corn and flaxseed oils which treated with 1500 ppm carrot cabbage and green pepper extracts were lower than other treatments, while iodine value were higher. It can be concluded that the additional of carrot, cabbage and green pepper extracts enhanced the acid, peroxide and iodine values of corn and linseed oils in the end of storage period.

Keywords: Antioxidants- carrot, cabbage and green pepper extract-Corn and linseed oils-Chemical properties. 


\section{INTRODUCTION}

Vegetables are good sources of natural antioxidant such as vitamins, minerals and phenolic compounds (Zhang and Hamauzu 2004). Fruits and vegetables are rich sources of various phytonutrients, many of which have antioxidant properties. In addition to the well-known antioxidants, vitamins $C$ and $E$, and $B$ carotene, fruits and vegetables contain other phytonutrients which significantly contribute to antioxidant activity and other health benefits (Alasalvar et al., 2005).

Carrot (Daucus carota) is one of the important root vegetable crops and is highly nutritious as it contains appreciable amount of vitamins B1, B2, B6 and B12. It also contains many important minerals (Ong and Chytil 1983). in addition (Torronen et al., 1996) and (Sharma et al., 2012). Carrot is one of the important root vegetables rich in bioactive compounds like carotenoids and dietary fibers with appreciable levels of several other functional components having significant health-promoting properties and source of natural antioxidants having anticancer activity.

Cabbage is an excellent source of Vitamin C It also contains significant amounts of glutamine, an amino acid which has anti-inflammatory properties. Cabbage can also be included in dieting programs, as it is a low calorie food. It is a source of indole-3-carbinol, a compound used as an adjuvant therapy for recurrent respiratory papillomatosis, a disease of the head and neck caused by human papillomavirus that causes growths in the airway that can lead to death (Butnariu, 2008).

Green pepper is one of the most widely used spices and is available in black, green, and white Govindarajon (1997). Peppers are cultivated in most temperate and tropical areas in the world. They are considered to be good sources of various 
nutritional compounds, such as carotenoids, flavonoids and mineral elements. There is a growing interest in peppers as a food containing beneficial compounds, especially because diet supplements do not provide the same nutritional and medicinal benefits as fresh fruits and vegetables (Bosland and Votava, 1999).

Vegetable oils have natural protection substances against deterioration caused by different factors, light, heat, basis, salts, enzymes and package material, these changes may by develop before or after modern processing storage, hydrolysis, auto-oxidation, polymerization, pyrolysis and uptake of flavor of foreign origin (Miller 1998).

\section{Flaxseed}

(limum

usitatissimum) is of the family linaceae, also known as linseeds (Sello, 2006). The funded Flaxseed or linseed (Linum usitatissimum L.) comes from the flax plant, an annual herb. The main importance of flaxseed is in the human nutrition sector because it is emerging as an important functional food ingredient thanks to the content of active compounds, pointed to provide health benefits. There are several ways to eat flaxseed: milled, in the form of oil or added to bakery product (Bernacchia et al., 2014). Linseed has been used for a very long time in human and animal nutrition. Currently, there is an increasing interest in linseed oil because of its particularly high content in $\alpha$-linolenic acid (ALA), an omega-3 fatty acid (FA) (Michotte et al., 2011).

Corn oil (maize oil) is obtained from seeds (kernels) that contain only $3-5 \%$ oil. Almost all commercial corn oil is obtained by pressing (Moreau 2005). Its main use is in cooking, where its high smoke point makes refined corn oil valuable frying oil, it is also a key ingredient in some margarine. Corn oil is generally less expensive than most other types of vegetable oils (Dupont et al., 1990). Corn oil contains 
omega- 3 and omega- 6 by $4: 1$ and the optimal ratio is believed to be 4: 1 or less (Daley et al., 2004). Corn oil has long been a popular cooking oil, because of its mild flavor, its stability (due to low levels of linolenate), and its reputation as a healthy edible oil (due its high levels of polyunsaturated fatty acids). Because of its higher levels of polyunsaturated than most other commodity vegetable oils (especially soy), corn oil was considered a superior oil and was sold at a premium (Frank 2011). In recent years the antioxidant properties of tocopherols (such as those found in corn oil) may be involved in combating atherosclerosis by preventing the oxidation of low-density lipoproteins (Saldeen et al., 1999).

Natural antioxidants from plant sources, the antioxidant and radical scavenging activities of some medicinal plants and fruits have been extensively studied in the last few decades (Singh et al., 2002). Antioxidants are widely used in food processing to prevent undesirable decomposition process and protect the quality of oil by retarding oxidant. Antioxidants compounds are an effective means for solving problem of rancidity and storage caused by the oxidation of lipids their effectiveness is generally attributed to their ability of reaction with free radicals and termination of chain reaction between unsaturated fatty acids and oxygen (EL-Jamal, 2001).

Chemical properties play an important role on oil quality, which can be evaluated by different constants such as acid value (AV), thiobarbituric acid (TBA) test, peroxide value (PV), iodine value (IV), Kreis Value (KV), and total carbonyl compounds (TC). These constituents are used to express the degree of oil deterioration (Wanasundara et al., 1994).

Consequently, this investigation aims to evaluate the chemical composition of carrot, cabbage and pepper, and 
effect of phenolic and flavonoids content of carrot, cabbage and pepper extracts on some chemical properties of corn and linseed oils during storage period.

\section{MATERIALS and METHODS}

\section{Materials}

Carrots, cabbage, green pepper, corn and flaxseed oil were obtained from local market in Egypt Chemical were Burch aced from El-gomhoria Company, Cairo, Egypt.

\section{Methods}

\section{Preparation of Carrots, cabbage and green pepper:}

Carrot, cabbage and green pepper cleaned from extraneous matter and properly washed with tab water then dried in air-oven for $24 \mathrm{~h}$ at $40{ }^{\circ} \mathrm{C}$ and then crushed into fine powder.

\section{Preparation of Carrots, cabbage and green pepper extracts:}

The dried Carrots, cabbage and green pepper ground in a blender to form powder, thereafter, $10 \mathrm{~g}$ of the powder macerated in $100 \mathrm{ml}$ absolute ethanol and the extraction repeated three times. The extracts filtered through Whatman filter paper (No. 40) and concentrate in a rotary evaporator under reduced pressure.

Corn and linseed oils storied (Six months) at room temperature $\left(25 \pm 5^{\circ} \mathrm{c}\right)$ after additional $500 \mathrm{ppm}, 1000 \mathrm{ppm}$ and $1500 \mathrm{ppm}$ from synthetic antioxidants (200 ppm of BHT \& BHA), carrot, cabbage and green pepper extracts. Control corn and linseed oils and treated samples with extracts analyzed every month for acid, peroxide and iodine values during storage period.

\section{Chemical analysis of vegetables:}

Determination of moisture, crude protein, crude lipids ash and fibers

Moisture, Crude protein, Crude lipids and Ash content of the carrots, cabbage and green pepper was determined according to the method described by AOAC (2000). 


\section{Determination}

of

carbohydrates:

Carbohydrates content was calculated by difference from the following equation: according to AOAC (2000).

Carbohydrates content $\%=100$ $-($ Protein + Moisture + Ash + Lipids + Fiber)

\section{Chemical properties of oils:}

\section{Determination of acid, peroxide} and iodine value:

Acid, peroxide and iodine value was determined according to AOAC (2000).

\section{Determination of Flavonoids}

Compounds:

Flavonoids compounds were determined by HPLC according to the method of Mattila et al. (2000) as follow: $5 \mathrm{~g}$ of sample were mixed with methanol and centrifuged at $10000 \mathrm{rpm}$ for $10 \mathrm{~min}$. and the supernatant was filtered through a $0.2 \mu \mathrm{m}$ Millipore membrane filter then 1-3 ml was collected in a vial for injection into HPLC Hewllet Packared (series 1050) equipped with auto sampling injector, solvent degasser, ultraviolet (UV) detector set at $330 \mathrm{~nm}$ and quarter HP pump (series 1050). The column temperature was maintained at 35॰ C. Gradient separation was carried out with methanol and acetonitrile as mobile phase at flow rate of $1 \mathrm{ml} / \mathrm{min}$. Flavonoid acid standard from sigma Co. were dissolved in a mobile phase and injected into HPLC. Retention time and peak area were used to calculation of phenolic compounds concentration by the data analysis of HEWLLET Packared software.

\section{Determination of phenolic} Compounds:

Phenolic compounds
were determined by HPLC
according to Goupy et al. (1999)
as follow: $5 \mathrm{~g}$ of sample were
mixed with methanol and
centrifuged at $10000 \mathrm{rpm}$ for 10
min. and the supernatant was
filtered through a o.2 $\mu \mathrm{m}$
Millipore membrane filter then
$1-3$ ml was collected in a vial for
injection into HPLC Agilaut
(series 1200) equipped with auto


samplling injector, solvent degasser, ultraviolet (UV) detector set at $280 \mathrm{~nm}$ and quarternary HP pump (series 1100). The column temperature was maintained at $85^{\circ} \mathrm{C}$. Gradient separation was carried out with methanol and acetonitrile as mobile phase at flow rate of $1 \mathrm{ml} / \mathrm{min}$. phenolic acid standard from sigma Co. were dissolved in a mobile phase and injected into HPLC. Retention time and peak area were used to calculation of phenolic compounds concentration by the data analysis of HEWLLET Packared software. Aminex-carbohydrate HPX- 87C 300mm × 7.8mm.

\section{Instruments of High- Performance Liquid \\ Chromatography (HPLC)}

HPLC Agilent 1200 series equipped with Quaternary pump, Auto sampler, and column compartment set at $35^{\circ} \mathrm{C}$, Maltiwave length detector set at (230nm - 280nm) for detection phenolic / Flavonoid compounds and degasser. Coulmr. Used for fractionation Zorbas ODS $4.6 \times$
$250 \mathrm{~nm}$ and the flow rate of mobile phase run was $1 \mathrm{ml} / \mathrm{min}$.

Statistical analysis:

The statistical evaluation of the mean \pm stander deviation data was analyzed according to (Zar, 1984).

\section{RESULTS and DISCUSSION}

- Chemical composition of carrot, cabbage and green pepper.

From data in table (1) It can be noticed that moisture, crude protein, total lipids, ash, fiber and carbohydrate content of carrot were $(10.65,5.08,3,7$, 1.30 and 83.62), respectively, while these values were (4.23, $10.41, \quad 2.42,9.00, \quad 2.50$ and 75.67) for green pepper and the chemical composition of cabbage were $(9.63,10.33,2.45$, $9.00, \quad 1.30$ and 76.92), respectively. Such results are in agreement with those obtained by Elbasuony, (2014).

- Flavonoids content of cabbage, pepper and carrot extracts. 
Flavonoids are phenolic compound with high antioxidant activity. Moreover, they have antitumoral and antimicrobial activities and participate in the prevention of cardiovascular diseases (Nijveldt et $a \boldsymbol{a l}$., 2001) and (Cushine and Lamb 2005). From table (2) it can by noticed that cabbage extract contain flavonoids (ppm) as luteolin (152.74), narengin (139.77), rutin (315.70), hisperidin (112.85), rosmarinic (92.94), quercetrin (168.09), quercetin (44.40), hispertin (115.04), kampferol (21.68), apegnin (21.11) this results are agreement with

(Kusznierewicza et al., 2008). Who estimated that the content of bioactive compounds in cabbages derived from different regions and reported that the values of total polyphenols; flavonoids and flavanols were $3.69 \pm 0.37,4.91 \pm 0.52,3.7 \pm 0.37$, $2.74 \pm 0.27 \mathrm{mg}$ gallic acid equivalent "GAE"/g;1.82 \pm 0.21 , $2.42 \pm 0.24, \quad 1.82 \pm 0.19 \quad$ and $1.41 \pm 0.15 \mathrm{mg} \quad$ catechin equivalent " $\mathrm{CE} / \mathrm{g}$ and 3.05 $\pm 0.04,4.0670 .05,3.0170 .03$ and
2.370.02 $\mu \mathrm{g}$ catechin equivalent "CE" /g) for cabbages derived from England, Belgium, Germany and Poland regions, respectively. Moreover pepper extract contain luteolin (313.07), narengin (54.90), rutin (303.96), hisperidin (1068.34), rosmarinic (29.90), quercetrin (186.26), quercetin (28.53), hispertin (13.82), kampferol (24.37), apegnin (1.27) ppm, this results are agreement with (Bosland and Votava 1999). Who reported that the peppers are cultivated in most temperate and tropical areas in the world. They are considered to be good sources of various nutritional compounds, such as carotenoids, flavonoids and mineral elements, there is a growing interest in peppers as a food containing beneficial compounds, especially because diet supplements do not provide the same nutritional and medicinal benefits as fresh fruits and vegetables. Additional carrot extract contain luteolin (320.75), narengin (84.12), rutin (190.05), hisperidin (951.95), rosmarinic (84.08), quercetrin (354.45), 
quercetin (163.17), hispertin (231.56), kampferol (46.70), apegnin (12.58) ppm, this results are agreement (Yena et al., 2008). Studied the antioxidant composition (mg/g DM) in carrot with various treatment (means standard error, $\mathrm{n}=3$ ) and reported that total Phenolics and Total flavondoids of carrot were 3.72 and 3.02 (mg/g DM).

- Phenolic compounds content of cabbage, pepper and carrot extracts

From table (3) it can by noticed that cabbage extract contain gallic (318.86), pyrogallol (2395.99), 4-amino-benzoic (238.19), 3-oH-tyrosol (1221.05), protocatchuic (751.98), chlorogenic (341.03), catechein (845.63), catechol (554.26), caffeine (346.23), poH-benzoic (460.57), caffeic (373.01), vanillic (84.85), pcoumaric (104.33), ferulic (93.51), iso-ferulic (67.89), reversetrol (142.10), ellagic (260.22), alpha-coumaric (93.29), 3,4,5-methoxy-cinnamic (157.46), coumarin (64.64), salycillic (790.52), cinnamic
(20.78) ppm, this results are agreement (Watanabe et al., 2011). Mentioned that the total phenols of methanolic extracts from orange-colored and normal Chinese cabbage, the total phenols of methanolic extracts from orange-colored Chinese cabbage $(387 \pm 11 \mathrm{mg} / 100 \mathrm{~g}$ DW) was higher than the methanolic extracts from normal Chinese cabbage (263 \pm 2 $\mathrm{mg} / 100 \mathrm{~g}$ DW) $(\mathrm{P}<0.001)$. Moreover pepper extract contain Gallic (1764.71), pyrogallol (7194.00), 4-amino-benzoic (1226.44), 3-oH-tyrosol (3405.92), protocatchuic (4714.14), chlorogenic (4504.89), catechein (2694.35), catechol (706.49), caffeine (1272.03), P-oH-benzoic (1072.62), caffeic (357.11), vanillic (497.27), p-coumaric (416.88), ferulic (176.53), isoferulic (46.67), reversetrol (94.40), ellagic (1548.81), evanillic (4777.33), alphacoumaric (450.30) 3,4,5methoxy-cinnamic (77.02), coumarin (24.55), salycillic (612.12), cinnamic (27.00) ppm, this results are agreement (Reis 
et al., 2013). Who studded that phenolic compounds on a dry basis of pepper in natural and dried at temperatures of 45,55 and $65 \mathrm{C}^{\circ}$ and the values were $9748.22,1480.25,1450.70$ and $1415.44 \mathrm{mg}$ GAE $\mathrm{kg}^{-1}$, respectively.

Additional carrot extract contain Gallic (1337.81), pyrogallol (3741.56), 4-amino-benzoic (497.37), 3-oH-tyrosol (2465.47), protocatchuic (3144.85), chlorogenic (4427.13), catechein (2361.11), catechol (527.13), caffeine (319.19), $\mathrm{P}-\mathrm{oH}$-benzoic (1387.60), caffeic (1102.80), vanillic (594.78), p-coumaric (320.00), ferulic (207.92), isoferulic (119.13), reversetrol (41.01), ellagic (243.62), alphacoumaric (442.33) 3,4,5methoxy-cinnamic (276.65), coumarin (27.62), salycillic (1912.19), cinnamic (30.39) ppm, this results are agreement (Alasalvar et al., 2001). Mentioned that the total amount of phenolic in purple carrots was $74.6 \mathrm{mg} / 100 \mathrm{~g}$. Whereas the corresponding values in yellow, orange and white varieties ranged from 7.72 to $16.2 \mathrm{mg} / 100$ g.

- Acid values (mg $\mathrm{KOH}$ /gm oil) of corn and flaxseed oils as affected by BHT, BHA, carrot, green pepper, and cabbage extracts during storage period (Six months).

The development of free fatty acid content in oil is usually considered to be one of the main parameters used in evaluating the quality of firing oil (Sello, 2006). Table (4) showed the acid value of corn oil as affected by (BHT) and (BHA) during storage period (six month). From table (4) it can by noticed that acid value of corn oil increased from $(0.150)$ at zero time to (0.542) after six month for control sample, while the acid values of oils treated with (BHT) and (BHA) were $(0.143,0.156)$ and $(0.443$, $0.436)$, respectively. Moreover it can by observed that the addition of (BHT) and (BHA) reduced the values of acid value of corn oil in the end of storage period, this reduction in acid values due to synthetic antioxidants (BHT 
\& BHA) retard undesirable changes due to oxidation (Lagouri et al., 1992). In additional the same trend of results was confirmed by ElAgaimy et al., (1989) Who reported that the values of free acidity of corn oil were (0.09 0.16). Moreover, from table (5) it can by noticed that acid value of corn and linseed oils which treated with $(500,1000,1500$ ppm) carrot cabbage and green pepper extracts were lower than other treatments in the end of storage period (six months).

- Peroxide values (Meq/kg oil) of corn and linseed oil as affected by BHT, BHA, carrot, green pepper, and cabbage extracts during storage period (Six months).

In spite of the fact the peroxide value (P.V) is an important for the quality assessment of fats and crude oils, peroxide value was determined to follow up the antoxidation of fats and crude oils. Table (6) show the peroxide value of corn oil as affected by (BHT) and (BHA) during storage period (six month). From table (6) it can by noticed that the changes in the peroxide values of corn oil increased from (2.300) at zero time to (8.700) after six month for control sample, while the peroxide value of oil treated with (BHT) and (BHA) were $(2.267,2.333)$ and (7.333, 7.367), respectively. The same trend of results was confirmed by (El-Agaimy et al., 1989). Who stated that peroxide values were 1.02-9.6. From the same table (12) it can by observed that the addition of (BHT) and (BHA) reduced the values of the peroxide value of corn oil in the end of storage period. From table (7) it can by noticed that that peroxide values of corn and flaxseed oils which treated with 500,1000 and 1500 ppm carrot cabbage and green pepper extracts were lower than other treatments in the end of storage period (six months).

- Iodine values of corn and flaxseed oil as affected by BHT, BHA, carrot, green pepper, and cabbage extracts during storage period (Six months). 
Table (8) show the iodine value of corn oil as affected by (BHT) and (BHA) during storage period (six month). From table (8) it can by noticed that the iodine values of corn oil decreased from (132.82) at zero time to (105.75) after six month for control sample, while the iodine value of oil treated with (BHT) and (BHA) were (132.61, 132.40) and (116.11,118.44) respectively. The same trend of results was confirmed by (ElAgaimy et al., 1989) who reported that iodine values were 110.15-122.25. Also, it can by observed that the addition of (BHT) and (BHA) reduced the values of iodine value of corn oil in the end of storage period compared with control sample. From table (9) it can by concluded that the iodine value of corn oil and flaxseed oils which treated with 500, 1000 and $1500 \mathrm{ppm}$ carrot cabbage and green pepper extracts were higher than control sample and oils treated with synthetic antioxidants (BHA \&BHT) in the end of storage period (six months).

\section{REFERENCES}

\begin{abstract}
Alasalvar C; Al-Farsi M; Quantick PC; Shahidi F and Wiktorowicz R (2005):

Effect of chill storage and modified atmosphere packaging (MAP) on antioxidant activity, anthocyanins, carotenoids, phenolics and sensory quality of ready-to-eat shredded orange and purple carrots. Journal Nutrition, 121:50-56.
\end{abstract}

\section{Alasalvar C; Grigor J M; Zhang D; Quantick P C; and Shahidi F (2001): \\ Comparison of volatiles, phenolics, sugars, antioxidant vitamins, and sensory quality of different colored carrot varietie Journal of Agricultural and Food Chemistry, 49, 1410-1416.}

A. O. A. C (2000):

Official Methods of Analysis. Association of Official Analytical Chemical. E. U. A. 
Bernacchia R; Preti R; and Vinci G (2014):

Chemical Composition and Health Benefits of Flaxseed Austin. Journal of Nutrition and Food Scienc.

\section{Bosland PW and Votava E} J(1999):

Pepper vegetable and Spice Capsicums. CABI, New York, NY.

Butnariu M (2008):

Alimentaţia funcţionalăcu componente bioactive naturale în sindromul metabolic. Editori coordonatori Simona Dragan, Iosif Gergen, Carmen Socaciu, Editura Eurostampa, Timisoara, Capitolul II, pp. 95 - 209.

\section{Cushnie TP and Lamb A J} (2005):

Antimicrobial activity of flavonoids. International Journal of Antimicrobial Agents 26: 343-356.
Daley CA; Abbott A; Doyle P; Nader G; Larson S (2004):

A literature review of the value-added nutrients found in grass-fed beef products. California State University, Chico (College of Agriculture). Retrieved $-03-23$.

\section{Dupont J; White PJ;} Carpenter MP; Schaefer EJ; Meydani SN; Elson C E; Woods $M$ and Gorbach SL (1990):

Food uses and health effects of corn oil. J. Am. Coll. Nutr. 9 (5): 438-470.

\section{El-Agaimy M A; Khalil MF and Iskander MH (1989):}

Comparative studies on Egyptian and imported corn oil second conference of food science and technology for mediter anean contires 11-14 rarch Cairo, A. R. E.

\section{Elbasuony GF (2014):}

Protective Effect of Radish, cabbage and Jews 
Mallow on Heavy Metal

Toxicity in Rats. Benha

University.

\section{EL-Jamal RE (2001):}

Physical and Chemical Studies on Oil and Fats. Mansoura University. Master Thesis, Fac. Home Eco-Mansoura Univ.

\section{Frank D G (2011):}

Vegetable Oils in Food Technology Composition, Properties and Uses. Blackwell Publishing Ltd, 273,279, 282,286-289.

\section{Govindarajon VS (1997):}

Antioxidative compounds in spice. Food Sci. and Nutri., 9: 125-225.

\section{Goupy P; Hugues M; Biovin B} and Amiot MJ (1999):

Antioxidant Composition and activity of barley (Hordeum yulgare) and malt tracts and of isolated phenolic compounds. J. Sci. Food Agric.,79: 16251634.
Kusznierewicza B; Bartoszekb A; Wolskaa L; Drzewieckic J; Gorinsteind $\mathrm{S}$ and Namies'nika J (2008):

Partial characterization of white cabbages (Brassica oleracea var. capitata $f$. Alba) from different regions by glucosinolates, bioactive, total antioxidant activities and proteins. Food Science and Technology, Volume 41, Pages 1-9.

\section{Lagouri V; Belkas $G$ and} Doskou D (1992):

Composition and antioxidant activity of essential oils from oregno plants grown wild in Greece. Z. Labens Unters Forsch., 197: 20-23.

\section{Michotte D; Rogez H; Chirinos $\mathbf{R}$ and Mignolet $\mathbf{E}$ (2011): \\ Linseed oil stabilisation with pure natural phenolic compounds. Food Chemistry, Volume 129, Pages 1228-1231.}


Mattila P; Astola $\mathbf{J}$ and Kumpulainen J (2000):

Determination

of flavonoids in plant material by HPLC with diode-array and electroarray detections. J. Ajric. Food Chem.,48: 58345841.

\section{Miller D (1998):}

Lipid oxidantion. In Food Chemistry. Ch. 10, P: 5766.

\section{Moreau RA and Hicks KB (2005):}

The composition of corn oil obtained by the alcohol extraction of ground corn. Journal of the American Oil Chemists, Society, 82: 809-815.

\section{Nijveldt RJ; Vannood E;} Vanhoorn DE; Boelrns P; Vannorren $K$ and Vanleeuwen P (2001):

Flavonoids: a review of probable mechanisms of action and potential applications. American
Journal of Clinical Nutrition, 74:418-425.

Ong DE and Chytil F (1983):

Vitamins and hormones. New York: Academic Press, pp.40: 105-112.

Reis RC; Castro VC; Devilla CA; Oliveira CA; Barbosa LS and Rodovalho I V (2013):

Effect of drying temperature on the nutritional and antioxidant qualities of cumari peppers from Pará (Capsicum chinense Jacqui) Braz. J. Chem. Eng. vol.30 no.2.

\section{Saldeen T; Li DY and Mehta} JL (1999):

Differential effects of alpha and gammatocopherol on low-density lipoprotein oxidation, superoxide activity, platelet aggregation and arterial thrombogenesis, Journal of the American College of Cardiology, 34: 1208-1215. 
Singh RP; Murthy KN and Jayaprakasha GK (2002):

Studies on the antioxidant activity of pomegranate (Punica granatum) peel and seed extracts using in vitro models. J. Agr. Food Chem. 50: 81-86.

Sharma KD; Karki S; Thakur NS and Attri S (2012):

Chemical composition, functional properties and processing of carrot .J. food Sci. Technol. 49(1):22-32.

Sello AA (2006):

Biochemical and Nutritional Studies on Some Edible Fats and Oils. Mansoura University, submitted partial fulfillment Requirements for the Degree of Doctor of philosophy.

Torronen R; Sarkkinen E; Niskanen T; Tapola N; Kilpi K and Niskanen L (2012):

Postprandial glucose, insulin and glucagon-like peptide 1 responses to sucrose ingested with berries in healthy subjects. 107(10): 1445-51.

\section{Wanasundara U; Amarawicz} $R$ and Shahidi F (1994):

Isolation and Identification of an antioxidative component in conola. $\mathrm{J}$. Agric. Food chem., 42: 1285-1290.

\section{Watanabe M; Musumi $\mathrm{K}$ and} Ayugase Ju (2011):

Carotenoid pigment composition, polyphenol content, and antioxidant activities of extracts from orange-colored Chinese cabbage. Food Science and Technology 44: 19711975.

Yena YH; Shiha $\mathrm{CH}$ and Changb CH (2008):

Effect of adding ascorbic acid and glucose on the ant oxidative properties during storage of dried carrot. Food Chemistry 107: 265272. 


\section{Zar JH (1984):}

Biostatistical analysis.

Prentice Hall, Englewood,

N.J., pp. 718. carrot (Daucus carota L.).

Food Agric., Environ., 2:95-101.

\section{Zhang $D$ and Hamauzee $Y$ (2004):}

Phenolic compounds and their antioxidant properties in different tissuse of 
Table (1): Chemical composition of carrot, green pepper and cabbage

\begin{tabular}{|l|c|c|c|}
\hline Compounds (\%) & Carrot & Pepper & Cabbage \\
\hline Moisture content & $10.65 \pm 0.1$ & $4.23 \pm 0.10$ & $9.63 \pm 0.60$ \\
\hline Crude protein* & $5.08 \pm 0.20$ & $10.41 \pm 0.10$ & $10.33 \pm 0.74$ \\
\hline Total lipids* & $3.00 \pm 0.30$ & $2.42 \pm 0.71$ & $2.45 \pm 0.70$ \\
\hline Ash content* & $7.00 \pm 1.41$ & $9.00 \pm 1.41$ & $9.00 \pm 1.42$ \\
\hline Fiber* & $1.30 \pm 1.24$ & $2.50 \pm 1.10$ & $1.30 \pm 0.12$ \\
\hline Carbohydrates* & 83.62 & 75.67 & 76.92 \\
\hline
\end{tabular}

Values are means of four replicates \pm stander deviation

* On dray weight basis

Table (2) Flavonoids content of cabbage, pepper and carrot extracts (ppm).

\begin{tabular}{|l|c|c|c|}
\hline \multirow{2}{*}{\multicolumn{1}{c|}{$\begin{array}{c}\text { Flavonoids } \\
\text { (PPM) }\end{array}$}} & $\begin{array}{c}|c| \\
\text { Cabbage } \\
\text { extract }\end{array}$ & $\begin{array}{c}\text { Pepper } \\
\text { extract }\end{array}$ & $\begin{array}{c}\text { Carrot } \\
\text { extract }\end{array}$ \\
\cline { 2 - 4 } Luteolin & 152.74 & 313.07 & 320.75 \\
\hline Narengin & 139.77 & 54.90 & 84.12 \\
\hline Rutin & 315.70 & 303.96 & 190.05 \\
\hline Hisperidin & 112.85 & 1068.34 & 951.95 \\
\hline Rosmarinic & 92.94 & 29.90 & 84.08 \\
\hline Quercetrin & 168.09 & 186.26 & 354.45 \\
\hline Quercetin & 44.40 & 28.53 & 163.17 \\
\hline Hispertin & 115.04 & 13.82 & 231.56 \\
\hline Kampferol & 21.68 & 24.37 & 46.70 \\
\hline Apegnin & 21.11 & 1.27 & 12.58 \\
\hline
\end{tabular}


Table (3) Phenolic compounds content of cabbage, pepper and carrot extracts (ppm)

\begin{tabular}{|c|c|c|c|}
\hline \multirow{2}{*}{$\begin{array}{l}\text { Phenolic compounds } \\
\text { (ppm) }\end{array}$} & \multicolumn{3}{|c|}{ Extracts } \\
\hline & $\begin{array}{l}\text { Carrot } \\
\text { extract }\end{array}$ & $\begin{array}{l}\text { Pepper } \\
\text { extract }\end{array}$ & $\begin{array}{c}\text { Cabbage } \\
\text { extract }\end{array}$ \\
\hline Gallic & 1337.81 & 1764.71 & 318.86 \\
\hline Pyrogallol & 3741.56 & 7194.00 & 2395.99 \\
\hline Amino-benzoic-4 & 497.37 & 1226.44 & 238.19 \\
\hline OH-Tyrosol-3 & 2465.47 & 3405.92 & 1221.05 \\
\hline Protocatchuic & 3144.85 & 4714.14 & 751.98 \\
\hline Chlorogenic & 4427.13 & 4504.89 & 341.03 \\
\hline Catechein & 2361.11 & 2694.35 & 845.63 \\
\hline Catechol & 527.13 & 706.49 & 554.26 \\
\hline Caffeine & 319.19 & 1272.03 & 346.23 \\
\hline P-OH-benzoic & 1387.60 & 1072.62 & 460.57 \\
\hline Caffeic & 1102.80 & 357.11 & 373.01 \\
\hline Vanillic & 594.78 & 497.27 & 84.85 \\
\hline p-coumaric & 320.00 & 416.88 & 104.33 \\
\hline Ferulic & 207.92 & 176.53 & 93.51 \\
\hline Iso-ferulic & 119.13 & 46.67 & 67.89 \\
\hline Reversetrol & 41.01 & 94.40 & 142.10 \\
\hline Ellagic & 253.62 & 1548.81 & 260.22 \\
\hline e-vanillic & $\ldots$ & 4777.33 & $\ldots$ \\
\hline Alpha-coumaric & 442.33 & 450.30 & 93.29 \\
\hline methoxy-cinnamic-3,4,5 & 276.65 & 77.02 & 157.46 \\
\hline Coumarin & 27.62 & 24.55 & 64.64 \\
\hline Salycillic & 1912.19 & 612.12 & 790.52 \\
\hline Cinnamic & 30.39 & 27.00 & 20.78 \\
\hline
\end{tabular}


Table (4): Acid value of corn oil as affected by BHT, BHA, carrot, cabbage, green pepper and storage period (mg KOH /g oil)

\begin{tabular}{|c|c|c|c|c|c|c|c|c|c|c|c|c|}
\hline \multirow{3}{*}{$\begin{array}{c}\text { Storage } \\
\text { period } \\
\text { (Months) }\end{array}$} & \multirow{3}{*}{ Control } & \multicolumn{2}{|c|}{$\begin{array}{c}\text { Synthetic } \\
\text { antioxidant }\end{array}$} & \multicolumn{9}{|c|}{ Natural antioxidant } \\
\hline & & \multirow[b]{2}{*}{ BHT } & \multirow[b]{2}{*}{ ВНА } & \multicolumn{3}{|c|}{ Carrot } & \multicolumn{3}{|c|}{ Cabbage } & \multicolumn{3}{|c|}{ Green pepper } \\
\hline & & & & $\begin{array}{c}500 \\
\text { ppm }\end{array}$ & $\begin{array}{l}1000 \\
\text { ppm }\end{array}$ & $\begin{array}{l}1500 \\
\text { ppm }\end{array}$ & $\begin{array}{c}500 \\
\text { ppm }\end{array}$ & $\begin{array}{l}1000 \\
\text { ppm }\end{array}$ & $\begin{array}{l}1500 \\
\text { ppm }\end{array}$ & $\begin{array}{c}500 \\
\text { ppm }\end{array}$ & $\begin{array}{l}1000 \\
\text { ppm }\end{array}$ & $\begin{array}{l}1500 \\
\text { ppm }\end{array}$ \\
\hline Zero time & $\begin{array}{c}1.253 \pm \\
0.03\end{array}$ & $\begin{array}{c}1.247 \pm \\
0.03\end{array}$ & $\begin{array}{c}1.234 \pm \\
0.01\end{array}$ & $\begin{array}{c}1.328 \pm \\
0.15\end{array}$ & $\begin{array}{c}1.228 \pm \\
0.02\end{array}$ & $\begin{array}{c}1.222 \pm \\
0.03\end{array}$ & $\begin{array}{c}1.197 \pm \\
0.02\end{array}$ & $\begin{array}{c}1.141 \pm \\
0.07\end{array}$ & $\begin{array}{c}1.221 \pm \\
0.04\end{array}$ & $\begin{array}{c}1.216 \pm \\
0.00\end{array}$ & $\begin{array}{c}1.153 \pm \\
0.03\end{array}$ & $\begin{array}{c}1.134 \pm \\
0.06\end{array}$ \\
\hline 1 & $\begin{array}{c}1.421 \pm \\
0.02\end{array}$ & $\begin{array}{c}1.228 \pm \\
0.02\end{array}$ & $\begin{array}{c}1.253 \pm \\
0.02\end{array}$ & $\begin{array}{c}1.328 \pm \\
0.02\end{array}$ & $\begin{array}{c}1.290 \pm \\
0.02\end{array}$ & $\begin{array}{c}1.227 \pm \\
0.01\end{array}$ & $\begin{array}{c}1.284 \pm \\
0.03\end{array}$ & $\begin{array}{c}1.252 \pm \\
0.02\end{array}$ & $\begin{array}{c}1.272 \pm \\
0.01\end{array}$ & $\begin{array}{c}1.253 \pm \\
0.02\end{array}$ & $\begin{array}{c}1.216 \pm \\
0.04\end{array}$ & $\begin{array}{c}1.150 \pm \\
0.02\end{array}$ \\
\hline 2 & $\begin{array}{c}1.621 \pm \\
0.03\end{array}$ & $\begin{array}{c}1.415 \pm \\
0.03\end{array}$ & $\begin{array}{c}1.440 \pm \\
0.03\end{array}$ & $\begin{array}{c}1.546 \pm \\
0.01\end{array}$ & $\begin{array}{c}1.515 \pm \\
0.02\end{array}$ & $\begin{array}{c}1.415 \pm \\
0.02\end{array}$ & $\begin{array}{c}1.496 \pm \\
0.00\end{array}$ & $\begin{array}{c}1.468 \pm \\
0.01\end{array}$ & $\begin{array}{c}1.371 \pm \\
0.03\end{array}$ & $\begin{array}{c}1.477 \pm \\
0.03\end{array}$ & $\begin{array}{c}1.403 \pm \\
0.06\end{array}$ & $\begin{array}{c}1.340 \pm \\
0.03\end{array}$ \\
\hline 3 & $\begin{array}{c}1.795 \pm \\
0.03\end{array}$ & $\begin{array}{c}1.590 \pm \\
0.02\end{array}$ & $\begin{array}{c}1.577 \pm \\
0.01\end{array}$ & $\begin{array}{c}1.689 \pm \\
0.01\end{array}$ & $\begin{array}{c}1.636 \pm \\
0.03\end{array}$ & $\begin{array}{c}1.583 \pm \\
0.01\end{array}$ & $\begin{array}{c}1.646 \pm \\
0.02\end{array}$ & $\begin{array}{c}1.580 \pm \\
0.01\end{array}$ & $\begin{array}{c}1.533 \pm \\
0.02\end{array}$ & $\begin{array}{c}1.614 \pm \\
0.01\end{array}$ & $\begin{array}{c}1.561 \pm \\
0.01\end{array}$ & $\begin{array}{c}1.508 \pm \\
0.01\end{array}$ \\
\hline 4 & $\begin{array}{c}2.188 \pm \\
0.02\end{array}$ & $\begin{array}{c}1.814 \pm \\
0.02\end{array}$ & $\begin{array}{c}1.820 \pm \\
0.03\end{array}$ & $\begin{array}{c}2.076 \pm \\
0.02\end{array}$ & $\begin{array}{c}1.879 \pm \\
1.07\end{array}$ & $\begin{array}{c}1.733 \pm \\
0.04\end{array}$ & $\begin{array}{c}2.026 \pm \\
0.02\end{array}$ & $\begin{array}{c}1.833 \pm \\
1.04\end{array}$ & $\begin{array}{c}1.689 \pm \\
0.04\end{array}$ & $\begin{array}{c}2.007 \pm \\
0.02\end{array}$ & $\begin{array}{c}1.805 \pm \\
1.02\end{array}$ & $\begin{array}{c}1.652 \pm \\
0.03\end{array}$ \\
\hline 5 & $\begin{array}{c}2.581 \pm \\
0.02\end{array}$ & $\begin{array}{c}2.138 \pm \\
0.04\end{array}$ & $\begin{array}{c}2.163 \pm \\
0.04\end{array}$ & $\begin{array}{c}2.450 \pm \\
0.02\end{array}$ & $\begin{array}{c}2.253 \pm \\
1.29\end{array}$ & $\begin{array}{c}2.082 \pm \\
0.02\end{array}$ & $\begin{array}{c}2.412 \pm \\
0.02\end{array}$ & $\begin{array}{c}2.197 \pm \\
1.25\end{array}$ & $\begin{array}{c}2.032 \pm \\
0.03 \\
\end{array}$ & $\begin{array}{c}2.375 \pm \\
0.03\end{array}$ & $\begin{array}{c}2.188 \pm \\
1.25 \\
\end{array}$ & $\begin{array}{c}2.013 \pm \\
0.01\end{array}$ \\
\hline 6 & $\begin{array}{c}2.899 \pm 0 \\
.02\end{array}$ & $\begin{array}{c}2.531 \pm \\
0.01\end{array}$ & $\begin{array}{c}2.512 \pm \\
0.01\end{array}$ & $\begin{array}{c}2.836 \pm \\
0.04\end{array}$ & $\begin{array}{c}2.683 \pm \\
1.54\end{array}$ & $\begin{array}{c}2.481 \pm \\
0.02\end{array}$ & $\begin{array}{c}2.768 \pm \\
0.03\end{array}$ & $\begin{array}{c}2.627 \pm \\
1.51\end{array}$ & $\begin{array}{c}2.431 \pm \\
0.02\end{array}$ & $\begin{array}{c}2.761 \pm \\
0.04\end{array}$ & $\begin{array}{c}2.618 \pm \\
1.50\end{array}$ & $\begin{array}{c}2.3100 \\
\pm \\
0.03\end{array}$ \\
\hline
\end{tabular}


Table (6): Peroxide value of corn oil as affected by BHT, BHA, carrot, cabbage, green pepper and storage period (mg KOH /g oil)

\begin{tabular}{|c|c|c|c|c|c|c|c|c|c|c|c|c|}
\hline \multirow{3}{*}{$\begin{array}{c}\text { Storage } \\
\text { period } \\
\text { (Months) }\end{array}$} & \multirow[b]{3}{*}{ Control } & \multicolumn{2}{|c|}{$\begin{array}{c}\text { Synthetic } \\
\text { antioxidant }\end{array}$} & \multicolumn{9}{|c|}{ Natural antioxidant } \\
\hline & & \multirow[t]{2}{*}{ BHT } & \multirow[t]{2}{*}{ BHA } & \multicolumn{3}{|c|}{ Carrot } & \multicolumn{3}{|c|}{ Cabbage } & \multicolumn{3}{|c|}{ Green pepper } \\
\hline & & & & $\begin{array}{c}500 \\
\text { ppm }\end{array}$ & $\begin{array}{l}1000 \\
\text { ppm }\end{array}$ & $\begin{array}{l}1500 \\
\text { ppm }\end{array}$ & $\begin{array}{c}500 \\
\text { ppm }\end{array}$ & $\begin{array}{l}1000 \\
\text { ppm }\end{array}$ & $\begin{array}{l}1500 \\
\text { ppm }\end{array}$ & $\begin{array}{c}500 \\
\text { ppm }\end{array}$ & $\begin{array}{l}1000 \\
\text { ppm }\end{array}$ & $\begin{array}{l}1500 \\
\text { ppm }\end{array}$ \\
\hline Zero time & $\begin{array}{c}2.300 \pm \\
0.02\end{array}$ & $\begin{array}{c}2.267 \pm \\
0.01\end{array}$ & $\begin{array}{c}2.333 \pm \\
0.01\end{array}$ & $\begin{array}{c}2.367 \pm \\
0.01\end{array}$ & $\begin{array}{c}2.333 \pm \\
0.01\end{array}$ & $\begin{array}{c}2.333 \pm \\
0.02\end{array}$ & $\begin{array}{c}2.200 \pm \\
0.03\end{array}$ & $\begin{array}{c}2.333 \pm \\
0.01\end{array}$ & $\begin{array}{c}2.267 \pm \\
0.01\end{array}$ & $\begin{array}{c}2.233 \pm \\
0.02\end{array}$ & $\begin{array}{c}2.333 \pm \\
0.01\end{array}$ & $\begin{array}{c}2.333 \pm \\
0.01\end{array}$ \\
\hline 1 & $\begin{array}{c}3.200 \pm \\
0.02\end{array}$ & $\begin{array}{c}2.800 \pm \\
0.02\end{array}$ & $\begin{array}{c}2.800 \pm \\
0.02\end{array}$ & $\begin{array}{c}3.167 \pm \\
0.01\end{array}$ & $\begin{array}{c}3.100 \pm \\
0.33\end{array}$ & $\begin{array}{c}3.067 \pm \\
0.02\end{array}$ & $\begin{array}{c}3.067 \pm \\
0.02\end{array}$ & $\begin{array}{c}2.967 \pm \\
0.30\end{array}$ & $\begin{array}{c}2.933 \pm \\
0.02\end{array}$ & $\begin{array}{c}2.933 \pm \\
0.04\end{array}$ & $\begin{array}{c}2.900 \pm \\
0.31\end{array}$ & $\begin{array}{c}2.867 \pm \\
0.04\end{array}$ \\
\hline 2 & $\begin{array}{c}4.367 \pm \\
0.01\end{array}$ & $\begin{array}{c}2.833 \pm \\
0.30\end{array}$ & $\begin{array}{c}4.233 \pm \\
0.11\end{array}$ & $\begin{array}{c}4.333 \pm \\
0.02\end{array}$ & $\begin{array}{c}4.100 \pm \\
0.43\end{array}$ & $\begin{array}{c}4.067 \pm \\
0.02\end{array}$ & $\begin{array}{c}4.233 \pm \\
0.04\end{array}$ & $\begin{array}{c}3.967 \pm \\
0.42\end{array}$ & $\begin{array}{c}3.967 \pm \\
0.01\end{array}$ & $\begin{array}{c}4.067 \pm \\
0.02\end{array}$ & $\begin{array}{c}3.900 \pm \\
0.40\end{array}$ & $\begin{array}{c}3.867 \pm \\
0.02\end{array}$ \\
\hline 3 & $\begin{array}{c}5.433 \pm \\
0.04\end{array}$ & $\begin{array}{c}5.100 \pm \\
0.02\end{array}$ & $\begin{array}{c}5.000 \pm \\
0.02\end{array}$ & $\begin{array}{c}5.200 \pm \\
0.04\end{array}$ & $\begin{array}{c}5.000 \pm \\
0.53\end{array}$ & $\begin{array}{c}4.933 \pm \\
0.02\end{array}$ & $\begin{array}{c}5.133 \pm \\
0.02\end{array}$ & $\begin{array}{c}4.833 \pm \\
0.52\end{array}$ & $\begin{array}{c}4.667 \pm \\
0.05\end{array}$ & $\begin{array}{c}5.033 \pm \\
0.01\end{array}$ & $\begin{array}{c}4.800 \pm \\
0.49\end{array}$ & $\begin{array}{c}4.733 \pm \\
0.04\end{array}$ \\
\hline 4 & $\begin{array}{c}6.533 \pm \\
0.04\end{array}$ & $\begin{array}{c}5.400 \pm \\
0.03\end{array}$ & $\begin{array}{c}5.400 \pm \\
0.04\end{array}$ & $\begin{array}{c}6.267 \pm \\
0.02\end{array}$ & $\begin{array}{c}6.067 \pm \\
0.64\end{array}$ & $\begin{array}{c}5.767 \pm \\
0.03\end{array}$ & $\begin{array}{c}6.167 \pm \\
0.03\end{array}$ & $\begin{array}{c}5.933 \pm \\
0.62\end{array}$ & $\begin{array}{c}5.633 \pm \\
0.03\end{array}$ & $\begin{array}{c}6.100 \pm \\
0.02\end{array}$ & $\begin{array}{c}5.867 \pm \\
0.60\end{array}$ & $\begin{array}{c}5.567 \pm \\
0.03\end{array}$ \\
\hline 5 & $\begin{array}{c}7.633 \pm \\
0.05\end{array}$ & $\begin{array}{c}6.500 \pm \\
0.02\end{array}$ & $\begin{array}{c}6.367 \pm \\
0.03\end{array}$ & $\begin{array}{c}7.433 \pm \\
0.03\end{array}$ & $\begin{array}{c}7.133 \pm \\
0.75\end{array}$ & $\begin{array}{c}6.633 \pm \\
0.02\end{array}$ & $\begin{array}{c}7.333 \pm \\
0.04\end{array}$ & $\begin{array}{c}7.000 \pm \\
0.76\end{array}$ & $\begin{array}{c}6.467 \pm \\
0.02\end{array}$ & $\begin{array}{c}7.233 \pm \\
0.01\end{array}$ & $\begin{array}{c}6.933 \pm \\
0.73\end{array}$ & $\begin{array}{c}6.367 \pm \\
0.03\end{array}$ \\
\hline 6 & $\begin{array}{c}8.700 \pm \\
0.04\end{array}$ & $\begin{array}{c}7.333 \pm \\
0.02\end{array}$ & $\begin{array}{c}7.367 \pm \\
0.03\end{array}$ & $\begin{array}{c}8.533 \pm \\
0.03\end{array}$ & $\begin{array}{c}8.367 \pm \\
0.88\end{array}$ & $\begin{array}{c}7.767 \pm \\
0.02\end{array}$ & $\begin{array}{c}8.433 \pm \\
0.01\end{array}$ & $\begin{array}{c}8.233 \pm \\
0.88\end{array}$ & $\begin{array}{c}7.633 \pm \\
0.03\end{array}$ & $\begin{array}{c}8.367 \pm \\
0.04\end{array}$ & $\begin{array}{c}8.200 \pm \\
0.86\end{array}$ & $\begin{array}{c}7.567 \pm \\
0.02\end{array}$ \\
\hline
\end{tabular}


Table (7): Peroxide value of linseed oil as affected by BHT, BHA, carrot, cabbage, green pepper and storage period (mg KOH /g oil)

\begin{tabular}{|c|c|c|c|c|c|c|c|c|c|c|c|c|}
\hline \multirow{3}{*}{$\begin{array}{c}\text { Storage } \\
\text { period } \\
\text { (Months) }\end{array}$} & \multirow[b]{3}{*}{ Control } & \multicolumn{2}{|c|}{$\begin{array}{c}\text { Synthetic } \\
\text { antioxidant }\end{array}$} & \multicolumn{9}{|c|}{ Natural antioxidant } \\
\hline & & \multirow[t]{2}{*}{ BHT } & \multirow[t]{2}{*}{ BHA } & \multicolumn{3}{|c|}{ Carrot } & \multicolumn{3}{|c|}{ Cabbage } & \multicolumn{3}{|c|}{ Green pepper } \\
\hline & & & & $\begin{array}{c}500 \\
\text { ppm }\end{array}$ & $\begin{array}{l}1000 \\
\text { ppm }\end{array}$ & $\begin{array}{l}1500 \\
\text { ppm }\end{array}$ & $\begin{array}{c}500 \\
\text { ppm }\end{array}$ & $\begin{array}{l}1000 \\
\text { ppm }\end{array}$ & $\begin{array}{l}1500 \\
\text { ppm }\end{array}$ & $\begin{array}{c}500 \\
\text { ppm }\end{array}$ & $\begin{array}{l}1000 \\
\text { ppm }\end{array}$ & $\begin{array}{l}1500 \\
\text { ppm }\end{array}$ \\
\hline $\begin{array}{l}\text { Zero } \\
\text { time }\end{array}$ & $\begin{array}{c}4.867 \pm \\
0.01\end{array}$ & $\begin{array}{c}4.833 \pm \\
0.01\end{array}$ & $\begin{array}{c}4.800 \pm \\
0.02\end{array}$ & $\begin{array}{c}4.800 \pm \\
0.02\end{array}$ & $\begin{array}{c}4.800 \pm \\
0.00\end{array}$ & $\begin{array}{c}4.700 \pm \\
0.02\end{array}$ & $\begin{array}{c}4.700 \pm \\
0.03\end{array}$ & $\begin{array}{c}4.867 \pm \\
0.01\end{array}$ & $\begin{array}{c}4.700 \pm \\
0.04\end{array}$ & $\begin{array}{c}4.833 \pm \\
0.01\end{array}$ & $\begin{array}{c}4.733 \pm \\
0.03\end{array}$ & $\begin{array}{c}4.800 \pm \\
0.02\end{array}$ \\
\hline 1 & $\begin{array}{c}5.600 \pm \\
0.02\end{array}$ & $\begin{array}{c}5.200 \pm \\
0.02\end{array}$ & $\begin{array}{c}5.167 \pm \\
0.01\end{array}$ & $\begin{array}{c}5.200 \pm \\
0.02\end{array}$ & $\begin{array}{c}5.467 \pm \\
0.02\end{array}$ & $\begin{array}{c}5.400 \pm \\
0.00\end{array}$ & $\begin{array}{c}4.900 \pm \\
0.02\end{array}$ & $\begin{array}{c}5.433 \pm \\
0.01\end{array}$ & $\begin{array}{c}5.367 \pm \\
0.01\end{array}$ & $\begin{array}{c}4.733 \pm \\
0.01\end{array}$ & $\begin{array}{c}5.367 \pm \\
0.01\end{array}$ & $\begin{array}{c}5.333 \pm \\
0.01\end{array}$ \\
\hline 2 & $\begin{array}{c}7.633 \pm \\
0.03\end{array}$ & $\begin{array}{c}5.667 \pm \\
0.04\end{array}$ & $\begin{array}{c}5.700 \pm \\
0.04\end{array}$ & $\begin{array}{c}7.233 \pm \\
0.01\end{array}$ & $\begin{array}{c}6.500 \pm \\
0.037\end{array}$ & $\begin{array}{c}5.933 \pm \\
0.01\end{array}$ & $\begin{array}{c}6.867 \pm \\
0.01\end{array}$ & $\begin{array}{c}6.400 \pm \\
0.02\end{array}$ & $\begin{array}{c}5.833 \pm \\
0.02\end{array}$ & $\begin{array}{c}6.667 \pm \\
0.01\end{array}$ & $\begin{array}{c}6.300 \pm \\
0.00\end{array}$ & $\begin{array}{c}5.733 \pm \\
0.03\end{array}$ \\
\hline 3 & $\begin{array}{c}8.567 \pm \\
0.03\end{array}$ & $\begin{array}{c}6.700 \pm \\
0.03\end{array}$ & $\begin{array}{c}6.600 \pm \\
0.02\end{array}$ & $\begin{array}{c}8.200 \pm \\
0.02\end{array}$ & $\begin{array}{c}7.300 \pm \\
0.05\end{array}$ & $\begin{array}{c}6.900 \pm \\
0.02\end{array}$ & $\begin{array}{c}7.867 \pm \\
0.01\end{array}$ & $\begin{array}{c}7.100 \pm \\
0.02\end{array}$ & $\begin{array}{c}6.867 \pm \\
0.01\end{array}$ & $\begin{array}{c}7.733 \pm \\
0.01\end{array}$ & $\begin{array}{c}7.067 \pm \\
0.02\end{array}$ & $\begin{array}{c}6.800 \pm \\
0.00\end{array}$ \\
\hline 4 & $\begin{array}{c}9.500 \pm \\
0.02\end{array}$ & $\begin{array}{c}7.200 \pm \\
0.02\end{array}$ & $\begin{array}{c}7.167 \pm \\
0.01\end{array}$ & $\begin{array}{c}9.133 \pm \\
0.03\end{array}$ & $\begin{array}{c}8.200 \pm \\
0.04\end{array}$ & $\begin{array}{c}7.433 \pm \\
0.01\end{array}$ & $\begin{array}{c}8.800 \pm \\
0.02\end{array}$ & $\begin{array}{c}8.000 \pm \\
0.02\end{array}$ & $\begin{array}{c}7.367 \pm \\
0.01\end{array}$ & $\begin{array}{c}8.600 \pm \\
0.02\end{array}$ & $\begin{array}{c}7.900 \pm \\
0.02\end{array}$ & $\begin{array}{c}7.300 \pm \\
0.02\end{array}$ \\
\hline 5 & $\begin{array}{c}10.433 \pm \\
0.04\end{array}$ & $\begin{array}{c}8.200 \pm \\
0.02\end{array}$ & $\begin{array}{c}8.100 \pm \\
0.02\end{array}$ & $\begin{array}{c}9.900 \pm \\
0.02\end{array}$ & $\begin{array}{c}9.033 \pm \\
0.01\end{array}$ & $\begin{array}{c}8.433 \pm \\
0.01\end{array}$ & $\begin{array}{c}9.700 \pm \\
0.02\end{array}$ & $\begin{array}{c}8.833 \pm \\
0.03\end{array}$ & $\begin{array}{c}8.367 \pm \\
0.01\end{array}$ & $\begin{array}{c}9.433 \pm \\
0.01\end{array}$ & $\begin{array}{c}8.700 \pm \\
0.02\end{array}$ & $\begin{array}{c}8.300 \pm \\
0.02 \\
\end{array}$ \\
\hline 6 & $\begin{array}{c}11.300 \pm \\
0.05\end{array}$ & $\begin{array}{c}9.100 \pm \\
0.02\end{array}$ & $\begin{array}{c}9.067 \pm \\
0.03\end{array}$ & $\begin{array}{c}10.50 \pm \\
0.02\end{array}$ & $\begin{array}{c}10.067 \pm \\
0.02\end{array}$ & $\begin{array}{c}9.700 \pm \\
0.03\end{array}$ & $\begin{array}{c}10.167 \pm \\
0.01\end{array}$ & $\begin{array}{c}10.00 \pm \\
0.0\end{array}$ & $\begin{array}{c}9.467 \pm \\
0.01\end{array}$ & $\begin{array}{c}9.967 \pm \\
0.01\end{array}$ & $\begin{array}{c}9.700 \pm \\
0.03\end{array}$ & $\begin{array}{c}9.333 \pm \\
0.03\end{array}$ \\
\hline
\end{tabular}


Table (8): Iodine value of corn oil as affected by BHT, BHA, carrot, cabbage, green pepper and storage period (mg KOH /g oil)

\begin{tabular}{|c|c|c|c|c|c|c|c|c|c|c|c|c|}
\hline \multirow{3}{*}{$\begin{array}{c}\text { Storage } \\
\text { period } \\
\text { (Months) }\end{array}$} & \multirow[b]{3}{*}{ Control } & \multicolumn{2}{|c|}{$\begin{array}{c}\text { Synthetic } \\
\text { antioxidant }\end{array}$} & \multicolumn{9}{|c|}{ Natural antioxidant } \\
\hline & & \multirow[t]{2}{*}{ BHT } & \multirow[t]{2}{*}{ BHA } & \multicolumn{3}{|c|}{ Carrot } & \multicolumn{3}{|c|}{ Cabbage } & \multicolumn{3}{|c|}{ Green pepper } \\
\hline & & & & $\begin{array}{c}500 \\
\text { ppm }\end{array}$ & $\begin{array}{l}1000 \\
\text { ppm }\end{array}$ & $\begin{array}{l}1500 \\
\text { ppm }\end{array}$ & $\begin{array}{c}500 \\
\text { ppm }\end{array}$ & $\begin{array}{l}1000 \\
\text { ppm }\end{array}$ & $\begin{array}{l}1500 \\
\text { ppm }\end{array}$ & $\begin{array}{l}500 \\
\text { ppm }\end{array}$ & $\begin{array}{l}1000 \\
\text { ppm }\end{array}$ & $\begin{array}{l}1500 \\
\text { ppm }\end{array}$ \\
\hline $\begin{array}{l}\text { Zero } \\
\text { time }\end{array}$ & $\begin{array}{c}132.82 \pm \\
0.73\end{array}$ & $\begin{array}{c}132.61 \pm \\
1.01\end{array}$ & $\begin{array}{c}132.40 \pm \\
1.47\end{array}$ & $\begin{array}{c}132.82 \pm \\
0.73\end{array}$ & $\begin{array}{c}131.98 \pm \\
1.27\end{array}$ & $\begin{array}{c}133.03 \pm \\
0.37\end{array}$ & $\begin{array}{c}132.61 \pm \\
0.63\end{array}$ & $\begin{array}{c}133.03 \pm \\
0.366\end{array}$ & $\begin{array}{c}132.82 \pm \\
0.37\end{array}$ & $\begin{array}{c}132.82 \pm \\
1.32\end{array}$ & $\begin{array}{c}133.25 \pm \\
0.63\end{array}$ & $\begin{array}{c}133.25 \pm \\
0\end{array}$ \\
\hline 1 & $\begin{array}{c}131.13 \pm \\
3.66\end{array}$ & $\begin{array}{c}131.34 \pm \\
3.30\end{array}$ & $\begin{array}{c}132.40 \pm \\
1.47\end{array}$ & $\begin{array}{c}130.70 \pm \\
1.27\end{array}$ & $\begin{array}{c}131.13 \pm \\
1.94\end{array}$ & $\begin{array}{c}132.40 \pm \\
1.47\end{array}$ & $\begin{array}{c}130.92 \pm \\
0.97\end{array}$ & $\begin{array}{c}131.34 \pm \\
1.68\end{array}$ & $\begin{array}{c}132.40 \pm \\
1.47\end{array}$ & $\begin{array}{c}131.34 \pm \\
2.20\end{array}$ & $\begin{array}{c}132.82 \pm \\
0.37\end{array}$ & $\begin{array}{c}133.03 \pm \\
0.37\end{array}$ \\
\hline 2 & $\begin{array}{c}129.02 \pm \\
3.66\end{array}$ & $\begin{array}{c}129.23 \pm \\
3.49\end{array}$ & $\begin{array}{c}131.55 \pm \\
2.93\end{array}$ & $\begin{array}{c}129.44 \pm \\
1.68\end{array}$ & $\begin{array}{c}130.07 \pm \\
2.77\end{array}$ & $\begin{array}{c}131.55 \pm \\
2.93\end{array}$ & $\begin{array}{c}129.86 \pm \\
1.60\end{array}$ & $\begin{array}{c}130.50 \pm \\
2.56\end{array}$ & $\begin{array}{c}131.55 \pm \\
2.93\end{array}$ & $\begin{array}{c}130.28 \pm \\
1.83\end{array}$ & $\begin{array}{c}131.98 \pm \\
1.10\end{array}$ & $\begin{array}{c}132.82 \pm \\
0.37\end{array}$ \\
\hline 3 & $\begin{array}{c}122.67 \pm \\
3.66\end{array}$ & $\begin{array}{c}123.09 \pm \\
3.36\end{array}$ & $\begin{array}{c}129.44 \pm \\
3.36\end{array}$ & $\begin{array}{c}127.53 \pm \\
2.91\end{array}$ & $\begin{array}{c}128.59 \pm \\
4.46\end{array}$ & $\begin{array}{c}129.44 \pm \\
3.36\end{array}$ & $\begin{array}{c}127.53 \pm \\
4.16\end{array}$ & $\begin{array}{c}128.17 \pm \\
5.08\end{array}$ & $\begin{array}{c}129.44 \pm \\
3.36\end{array}$ & $\begin{array}{c}128.80 \pm \\
1.10\end{array}$ & $\begin{array}{c}130.50 \pm \\
2.56\end{array}$ & $\begin{array}{c}131.55 \pm \\
2.93\end{array}$ \\
\hline 4 & $\begin{array}{c}116.33 \pm \\
3.66\end{array}$ & $\begin{array}{c}120.77 \pm \\
6.03\end{array}$ & $\begin{array}{c}122.88 \pm \\
3.49\end{array}$ & $\begin{array}{c}120.13 \pm \\
1.32\end{array}$ & $\begin{array}{c}121.61 \pm \\
3.19\end{array}$ & $\begin{array}{c}122.88 \pm \\
3.49\end{array}$ & $\begin{array}{c}120.34 \pm \\
2.04\end{array}$ & $\begin{array}{c}121.19 \pm \\
0.63\end{array}$ & $\begin{array}{c}122.88 \pm \\
3.49\end{array}$ & $\begin{array}{c}122.04 \pm \\
6.39\end{array}$ & $\begin{array}{c}123.52 \pm \\
8.80\end{array}$ & $\begin{array}{c}124.10 \pm \\
7.15\end{array}$ \\
\hline 5 & $\begin{array}{c}113.79 \pm \\
0.73\end{array}$ & $\begin{array}{c}118.02 \pm \\
7.72\end{array}$ & $\begin{array}{c}121.19 \pm \\
6.05\end{array}$ & $\begin{array}{c}118.65 \pm \\
3.30\end{array}$ & $\begin{array}{c}119.50 \pm \\
4.03\end{array}$ & $\begin{array}{c}121.19 \pm \\
6.05\end{array}$ & $\begin{array}{c}118.02 \pm \\
3.17\end{array}$ & $\begin{array}{c}119.29 \pm \\
3.86\end{array}$ & $\begin{array}{c}121.19 \pm \\
6.05\end{array}$ & $\begin{array}{c}120.13 \pm \\
4.68\end{array}$ & $\begin{array}{c}121.61 \pm \\
6.66\end{array}$ & $\begin{array}{c}123.30 \pm \\
9.29\end{array}$ \\
\hline 6 & $\begin{array}{c}105.75 \pm \\
3.66\end{array}$ & $\begin{array}{c}116.11 \pm \\
7.95\end{array}$ & $\begin{array}{c}118.44 \pm \\
7.33\end{array}$ & $\begin{array}{c}108.29 \pm \\
0.73\end{array}$ & $\begin{array}{c}110.40 \pm \\
3.36\end{array}$ & $\begin{array}{c}112.10 \pm \\
3.66\end{array}$ & $\begin{array}{c}109.98 \pm \\
1.83\end{array}$ & $\begin{array}{c}111.04 \pm \\
1.74\end{array}$ & $\begin{array}{c}114.21 \pm \\
0.0\end{array}$ & $\begin{array}{c}112.10 \pm \\
3.66\end{array}$ & $\begin{array}{c}114.42 \pm \\
6.66\end{array}$ & $\begin{array}{c}116.33 \pm \\
9.69\end{array}$ \\
\hline
\end{tabular}


Table (9): Iodine value of linseed oil as affected by BHT, BHA, carrot, cabbage, green pepper and storage period (mg KOH /g oil)

\begin{tabular}{|c|c|c|c|c|c|c|c|c|c|c|c|c|}
\hline \multirow{3}{*}{$\begin{array}{c}\text { Storage } \\
\text { period } \\
\text { (Months) }\end{array}$} & \multirow[b]{3}{*}{ Control } & \multicolumn{2}{|c|}{$\begin{array}{c}\text { Synthetic } \\
\text { antioxidant }\end{array}$} & \multicolumn{9}{|c|}{ Natural antioxidant } \\
\hline & & \multirow[b]{2}{*}{ BHT } & \multirow[b]{2}{*}{ BHA } & \multicolumn{3}{|c|}{ Carrot } & \multicolumn{3}{|c|}{ Cabbage } & \multicolumn{3}{|c|}{ Green pepper } \\
\hline & & & & $\begin{array}{c}500 \\
\text { ppm }\end{array}$ & $\begin{array}{l}500 \\
\text { ppm }\end{array}$ & $\begin{array}{c}500 \\
\text { ppm }\end{array}$ & $\begin{array}{c}500 \\
\text { ppm }\end{array}$ & $\begin{array}{c}500 \\
\text { ppm }\end{array}$ & $\begin{array}{c}500 \\
\text { ppm }\end{array}$ & $\begin{array}{l}500 \\
\text { ppm }\end{array}$ & $\begin{array}{c}500 \\
\text { ppm }\end{array}$ & 1500 \\
\hline $\begin{array}{l}\text { Zero } \\
\text { time }\end{array}$ & $\begin{array}{c}190.773 \pm \\
0.73\end{array}$ & $\begin{array}{c}190.562 \pm \\
1.32\end{array}$ & $\begin{array}{c}190.985 \pm \\
1.27\end{array}$ & $\begin{array}{c}190.562 \pm \\
1.83\end{array}$ & $\begin{array}{c}190.350 \pm \\
0.00\end{array}$ & $\begin{array}{c}190.773 \pm \\
1.32\end{array}$ & $\begin{array}{c}190.350 \pm \\
0.63\end{array}$ & $\begin{array}{c}190.985 \pm \\
2.20\end{array}$ & $\begin{array}{c}190.139 \pm \\
0.37\end{array}$ & $\begin{array}{c}190.773 \pm \\
0.73\end{array}$ & $\begin{array}{c}190.985 \pm \\
0.63\end{array}$ & $\begin{array}{c}190.350 \pm \\
0.00\end{array}$ \\
\hline 1 & $\begin{array}{c}182.948 \pm \\
0.37\end{array}$ & $\begin{array}{c}188.870 \pm \\
0.73\end{array}$ & $\begin{array}{c}188.658 \pm \\
0.37\end{array}$ & $\begin{array}{c}183.371 \pm \\
0.63\end{array}$ & $\begin{array}{c}184.640 \pm \\
0.63\end{array}$ & $\begin{array}{c}185.909 \pm \\
0.63\end{array}$ & $\begin{array}{c}183.794 \pm \\
0.37\end{array}$ & $\begin{array}{c}185.063 \pm \\
0.37\end{array}$ & $\begin{array}{c}186.332 \pm \\
0.37\end{array}$ & $\begin{array}{c}184.428 \pm \\
0.73\end{array}$ & $\begin{array}{c}185.486 \pm \\
0.37\end{array}$ & $\begin{array}{c}186.755 \pm \\
0.37\end{array}$ \\
\hline 2 & $\begin{array}{c}182.313 \pm \\
0.37\end{array}$ & $\begin{array}{c}187.389 \pm \\
0.37\end{array}$ & $\begin{array}{c}187.601 \pm \\
0.37\end{array}$ & $\begin{array}{c}182.736 \pm \\
0.63\end{array}$ & $\begin{array}{c}184.005 \pm \\
0.63\end{array}$ & $\begin{array}{c}184.851 \pm \\
0.37\end{array}$ & $\begin{array}{c}183.159 \pm \\
0.37\end{array}$ & $\begin{array}{c}184.428 \pm \\
0.37\end{array}$ & $\begin{array}{c}185.274 \pm \\
0.63\end{array}$ & $\begin{array}{c}183.582 \pm \\
0.37\end{array}$ & $\begin{array}{c}184.640 \pm \\
0.00\end{array}$ & $\begin{array}{c}185.909 \pm \\
0.63\end{array}$ \\
\hline 3 & $\begin{array}{c}180.621 \pm \\
0.37\end{array}$ & $\begin{array}{c}186.543 \pm \\
0.63\end{array}$ & $\begin{array}{c}186.332 \pm \\
0.37\end{array}$ & $\begin{array}{c}181.044 \pm \\
0.37\end{array}$ & $\begin{array}{c}181.679 \pm \\
1.47\end{array}$ & $\begin{array}{c}181.890 \pm \\
1.83\end{array}$ & $\begin{array}{c}180.833 \pm \\
0.00\end{array}$ & $\begin{array}{c}181.044 \pm \\
0.37\end{array}$ & $\begin{array}{c}182.948 \pm \\
1.83\end{array}$ & $\begin{array}{c}181.256 \pm \\
0.73\end{array}$ & $\begin{array}{c}181.467 \pm \\
1.10\end{array}$ & $\begin{array}{c}184.217 \pm \\
0.37\end{array}$ \\
\hline 4 & $\begin{array}{c}177.660 \pm \\
0.00\end{array}$ & $\begin{array}{c}185.697 \pm \\
0.37\end{array}$ & $\begin{array}{c}185.486 \pm \\
0.37\end{array}$ & $\begin{array}{c}178.083 \pm \\
0.73\end{array}$ & $\begin{array}{c}178.929 \pm \\
0.00\end{array}$ & $\begin{array}{c}179.987 \pm \\
0.97\end{array}$ & $\begin{array}{c}178.506 \pm \\
0.37\end{array}$ & $\begin{array}{c}179.352 \pm \\
0.73\end{array}$ & $\begin{array}{c}181.044 \pm \\
0.97\end{array}$ & $\begin{array}{c}178.718 \pm \\
0.37\end{array}$ & $\begin{array}{c}179.775 \pm \\
0.73\end{array}$ & $\begin{array}{c}183.371 \pm \\
1.10\end{array}$ \\
\hline 6 & $\begin{array}{c}172.796 \pm \\
0.97\end{array}$ & $\begin{array}{c}183.371 \pm \\
1.10\end{array}$ & $\begin{array}{c}183.159 \pm \\
0.97\end{array}$ & $\begin{array}{c}174.276 \pm \\
0.37\end{array}$ & $\begin{array}{c}177.449 \pm \\
0.37\end{array}$ & $\begin{array}{c}177.872 \pm \\
0.73\end{array}$ & $\begin{array}{c}175.968 \pm \\
0.37\end{array}$ & $\begin{array}{c}177.237 \pm \\
0.37\end{array}$ & $\begin{array}{c}178.929 \pm \\
0.63\end{array}$ & $\begin{array}{c}176.603 \pm \\
0.97\end{array}$ & $\begin{array}{c}177.660 \pm \\
0.64\end{array}$ & $\begin{array}{c}181.044 \pm \\
0.73\end{array}$ \\
\hline
\end{tabular}




\section{تطبيقات مستخلصات بعض الخضروات علي مدة تخزين

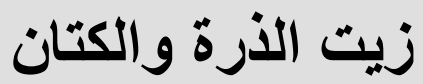

أحمد عبد الفتاح على أحمد ونوال عباس طاحون و رحاب نصر الدين عبد الله الهلالي

قسم الاقتصاد المنزلي - كلية التربية النوعية - جامعة بنها- جمهورية مصر العربية

تهدف هذه الدراسة إلى تقدير محتوى مستخلصات الكرنب والجزر و الفلفل الأخضر

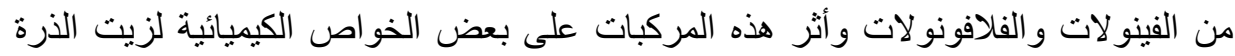

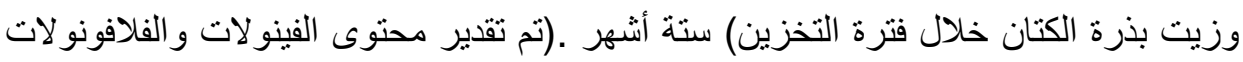

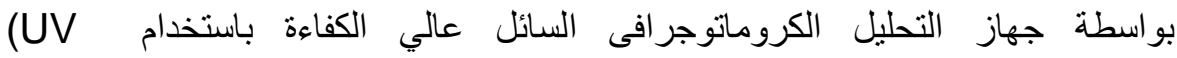

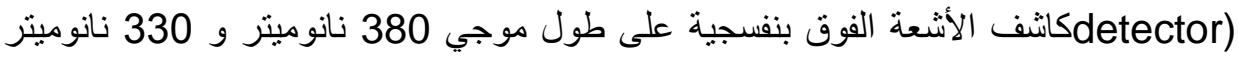

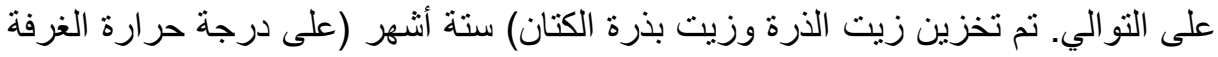
5×25درجة مئوية بعد إضافة

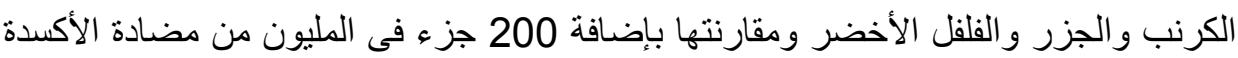

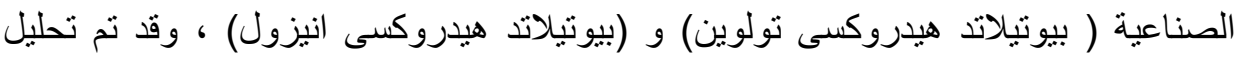

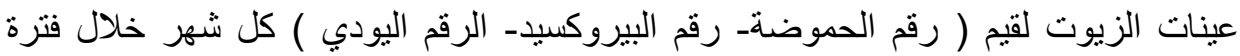

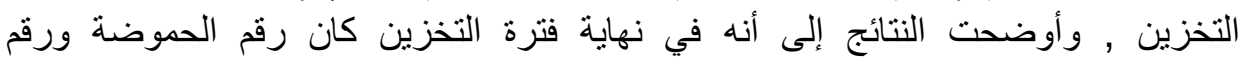

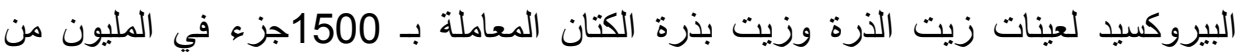

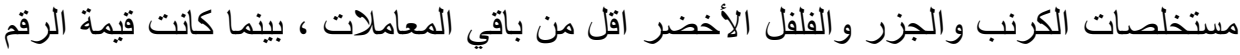

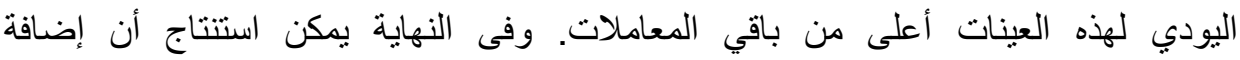

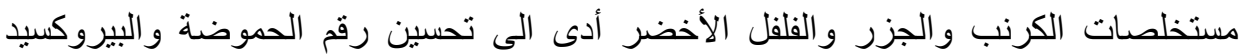
و الرقم اليودي في نهاية فترة التخزين.

الكلمات المفتاحية: مضادات الاكسدة- مستخلص الجزر و الكرنب و الفلفل الاخضر - زيت الذرة و الكتان- الخصائص الكيميائية 